\title{
TINJAUAN TERHADAP PILIHAN MAHASISWA AKUNTANSI PADA KARIR DI BIDANG SISTEM INFORMASI AKUNTANSI
}

\author{
Mia Ika Rahmawati ${ }^{1)}$; Anang Subardjo ${ }^{2)}$ \\ miaikarahmawati@stiesia.ac.id ${ }^{1)}$; anangsubardjo@stiesia.ac.id ${ }^{2)}$ \\ Jurusan Akuntansi, Sekolah Tinggi Ilmu Ekonomi Indonesia (Stiesia) Surabaya, Surabaya, \\ Indonesia
}

\begin{tabular}{l} 
Info Artikel \\
\hline Sejarah Artikel: \\
Diterima : 19 Mei 2020 \\
Disetujui : 15 Juli 2020 \\
Dipublikasikan : 15 \\
Agustus 2020 \\
\hline Keywords: \\
Mahasiswa; Pilihan karir; \\
Sistem Informasi \\
Akuntansi
\end{tabular}

\begin{abstract}
Abstrak
Revolusi Industri 4.0 adalah pengubah permainan untuk profesi di bidang sistem informasi akuntansi khususnya. Ini memotivasi peneliti untuk menganalisis lebih lanjut perspektif siswa pilihan karir dalam sistem informasi akuntansi. Tujuan dari penelitian ini adalah untuk mengeksplorasi minat siswa untuk memilih dan tidak memilih karir di Bidang Sistem Informasi Akuntansi. Penelitian ini dilakukan dengan menggunakan kuesioner. Responden adalah mahasiswa sarjana akuntansi. Hasil penelitian menunjukkan bahwa siswa yang tertarik dengan karir AIS lebih tinggi daripada mereka yang tidak tertarik. Siswa yang memilih dalam karir AIS ditentukan beberapa faktor seperti Kemudahan dalam menguasai materi kursus AIS, Saran dari pengawas akademik, Saran Dosen, Potensi gaji tinggi, dan minat pribadi dalam AIS. Sebaliknya, siswa yang tidak memilih karir di bidang AIS dengan delapan faktor utama, hanya ada 3 penyebab yaitu materi AIS sulit, peluang Karier tidak menjanjikan, dan tidak merasa cocok.
\end{abstract}

THE STUDENTS' PERSPECTIVES OF CAREER CHOICES IN ACCOUNTING INFORMATION SYSTEMS FIELD

\begin{abstract}
The Industrial Revolution 4.0 is a game changer for profession in the field of accounting information systems in particular. It motivates researchers to analyze further students perspectives of career choices in accounting information systems. The aim of this study is to explore the interests of students to choose and not choose a career in Accounting Information Systems Field. This study was conducted using questionnaires. The respondents were accounting undergraduate students. The results show that students who are interested in AIS careers are higher than those who are not interested. Students who choose in AIS careers are determined several factors like Ease in mastering AIS course material, Suggestion from academic Supervisor, Lecturer Suggestions, Potential high salary, and Personal interest in AIS. On contrary, students who did not choose career in AIS field with the main eight factors, there are only 3 causes that is AIS material is difficult, Career opportunities were not promising, and not feeling suitable.
\end{abstract}




\section{PENDAHULUAN}

Revolusi Industri (R.I) 4.0 masih menjadi topik penelitian yang menjadi perhatian besar saat ini. Fenomena ini akan terus berlangsung dikarenakan banyak yang belum memahami apa, kapan dan mengapa kita berpindah dari Revolusi Industri 3.0 ke 4.0. Revolusi Industri dimulai pada akhir abad ke 18 dimana Revolusi Industri pada abad ini adalah di titik beratkan pada proses manufaktur dengan bantuan mesin. Dilanjutkan pada awal abad ke 20, dimana revolusi industri berkembang dengan menggunakan listrik. Kemudian berlanjut kepada Revolusi Industri 3.0 yang dimulai sekitar tahun 1970an, dimana pada masa itu telah menggunakan proses manufaktur otomatis dengan mulai menggunakan teknologi informasi. Sedangkan Revolusi Industri 4.0 dimulai pada saat ini dengan menitikberatkan penggunakan Cyber-PhysicalProduction Systems (CPPS). Sementara survei yang dilakukan oleh Society of Information Management di tahun 2018 menunjukkan bahwa rata-rata presentase pengeluaran TI selama 12 tahun terakhir (2007 s/d 2018) adalah sebesar 4,76\% dari pendapatan. Sedangkan sejak tujuh tahun terakhir, (2012-2018), perusahaan yang disurvei menghabiskan dana di atas rata-rata presentase tersebut dan di tiga tahun terakhir menunjukkan peningkatan drastis dari $5,04 \%$ di tahun 2016 naik 1\% lebih menjadi 6,08\% di tahun 2017 dan turun lebih sedikit menjadi 5,9\% di tahun 2018 (Kappelman, 2018). Data-data tersebut menunjukkan bahwa organisasi modern percaya bahwa adopsi TI dapat memberikan kontribusi positif bagi kinerja perusahaan. Belanja TI tersebut memberikan latar belakang kepada perkembangan RI 4.0 dimana organisasi bisnis modern semakin banyak menghabiskan dananya untuk inverstasi TI. Tak terkecuali fungsi akuntansi juga termasuk sektor yang terpengaruh dengan perkembangan TI dan membelanjakan dana yang besar untuk TI. Adopsi TI yang lebih tinggi diantara fungsi akuntansi dikaitkan dengan mendorong peningkatan produktivitas di kalangan profesional akuntansi. Adanya peningkatan investasi dalam audit perangkat lunak dan aplikasi berbagi pengetahuan untuk mendukung perusahaan akuntansi untuk mengumpulkan, mengatur, memproses, mengevaluasi dan menyajikan data keuangan (Curtis et al., 2009). Selain itu, kerja tim sangat penting di masyarakat perusahaan akuntansi ketika perikatan audit dilakukan oleh tim yang terdiri dari para profesional di peringkat yang berbeda, perusahaan akuntansi ini juga berinvestasi dalam teknologi groupware untuk meningkatkan kolaborasi dan komunikasi kerja dalam tim, sehingga meningkatkan produktivitas akuntansi (Vandenbosch \& Ginzberg, 1997). Disamping itu, munculnya komputasi awan (Cloud Computing), XBRL, dan analitis bisnis telah berubah cara perusahaan melaporkan kinerja keuangan dan membuat keputusan bisnis (Pan et al., 2015).

Dikarenakan peningkatan investasi TI di antara berbagai fungsi akuntansi, maka tidaklah sulit untuk memahami alasannya ada peningkatan permintaan untuk pengetahuan IT tingkat lanjut dan keterampilan untuk para profesional akuntansi. Pengetahuan IT tingkat lanjut dan keterampilan seperti forensik TI, audit TI, dan analisis data masih masih sangatlah rendah dalam jumlah di antara para profesional akuntansi. Industri akuntansi sangat membutuhkan sekelompok profesional sistem informasi akuntansi (SIA) yang kompeten yang dapat menangani tuntutan TI di Indonesia pada bidang jasa dan aktivitas akuntansi. Panggilan ini diperlukan untuk memenuhi kebutuhan untuk pendidik akuntansi serta stakeholders untuk meninjau kurikulum SIA yang saat ini diberlakukan dan menilai apakah kurikulum saat ini memadai untuk membekali siswa akuntansi dengan pengetahuan IT tingkat lanjut dan keterampilan SIA (Arens \& Elder, 2006; Arnold \& Sutton, 2007; Curtis et al., 2009).

Salah satu bidang akuntansi yang sangat dipengaruhi oleh pengembangan TI adalah SIA. Pada dasarnya akuntansi siklus pada komputer berbasis SIA sama dengan SIA berbasis manual, artinya aktivitas akuntansi yang harus dilakukan untuk menghasilkan laporan keuangan yang tidak didapat dihapus. Komputer berbasis SIA hanya mengubah karakter suatu kegiatan. 
Akuntan adalah profesi yang banyak berhubungan dengan kegiatan TI di era revolusi industri 4.0. Pengembangan SIA dan proses audit sebagai hasil dari kemajuan TI akan membawa peluang untuk akuntan. Peluang ini dapat dimanfaatkan oleh akuntan yang memiliki pengetahuan yang memadai tentang berbasis komputer SIA dan audit. Sebagai gantinya, akuntan yang tidak memiliki pengetahuan yang cukup tentang SIA dan audit berbasis komputer akan terlantar posisinya dikarenakan tidak dapat memberikan layanan yang dibutuhkan oleh klien.

Meningkatkan kualitas pembelajaran mahasiswa serta pengalaman dan hasil selalu menjadi fokus penelitian dalam ilmu pendidikan dan psikologi. Peran penting para profesional SIA menjadi motivasi peneliti untuk menganalisis lebih lanjut minat mahasiswa pada profesi di bidang SIA. Penelitian ini penting dilakukan karena TI dan SI makin bertumbuh sangat cepat di era revolusi industri 4.0 dan telah menjadi bagian integral dari kehidupan kita. TI dan SI telah dan akan membuat kontribusi signifikan untuk meningkatkan produktivitas, kreativitas dan daya saing individu, organisasi dan negara. Sedangkan McInerney et al. (2008) menemukan bahwa semua mahasiswa dalam penelitian menunjukkan bahwa minat mereka pada komputer yang memotivasi mereka untuk memilih jurusan yang berhubungan dengan IT dan harapan kedepannya akan bekerja dengan karir yang berhubungan dengan IT. Kemudian McInerney et al. (2008) juga menemukan keterampilan interpersonal, keterampilan menulis, dan pemikiran logis sebagai faktor kunci kesuksesan di jurusan Informatika. Hasil penelitian tersebut terkait dengan faktor-faktor yang mempengaruhi pilihan pembelajaran dan akuntansi profesi sistem menunjukkan hasil yang beragam. Vatanasakdakul dan Aoun (2011) meneliti tantangan mahasiswa akuntansi yang dihadapi dalam mempelajari Sistem Informasi Akuntansi (SIA) melalui investigasi faktor-faktor yang berkontribusi pada kesulitan mereka. Vatanasakdakul dan Aoun (2011) juga menunjukkan bahwa struktur mata kuliah, pengetahuan sistem informasi (SI), penilaian kritis berpikir, gaya mengajar dan itu ketersediaan bantuan akademik untuk mahasiswa memiliki pengaruh yang signifikan terhadap pemilihan mata kuliah SIA. Tujuan dari penelitian ini mengeksplorasi minat mahasiswa untuk memilih dan tidak memilih karir di bidang Sistem Informasi Akuntansi.

\section{TELAAH PUSTAKA}

\section{Pendekatan Teori pada Pengambilan Keputusan Karir}

Pendekatan teoritis untuk pengambilan keputusan karir didasarkan pada dua teori perspektif utama pilihan karir dan pengembangan: psikologis dan sosiologis (Brown, 2002). Pendekatan psikologis berusaha untuk menggambarkan atau menjelaskan cara individu membuat keputusan karier berdasarkan faktor individu yang meliputi kepribadian, minat, kemampuan dan kepuasan kerja karena faktor-faktor ini secara signifikan mempengaruhi cara individu berperilaku, berpikir, dan merespons untuk membuat pilihan karier. Di sisi lain, pendekatan sosiologis berusaha untuk mengembangkan proses pengambilan keputusan karir yang memungkinkan individu untuk mempertimbangkan relevansi berbagai faktor sebelum pengambilan keputusan karier mereka. Teori berbasis sosiologis berfokus pada dua faktor utama; demografis dan lingkungan (Johnson \& Mortimer 2002). Faktor demografis mengacu pada jenis kelamin, etnis, dan status sosial ekonomi dari keluarga. Sementara faktor lingkungan mengacu pada pengaruh sosial, seperti pengaruh keluarga anggota, teman sekolah, nilai-nilai dan praktik masyarakat, lingkungan kerja, koneksi kelaurga, struktur pasar tenaga kerja dan lingkungan ekonomi. 


\section{Pendekatan Psikologis untuk Pengambilan Keputusan Karir}

Teori kepribadian vokasional dan lingkungan kerja diperkenalkan oleh John Holland pada tahun 1959 dan menekankan pentingnya kecocokan antara pilihan vokasional dan lingkungan kerja (Spokane, Luchetta \& Richwine 2002). Hal tersebut dikembangkan dari teori Parsons tentang pandangan pilihan vokasional, yang menyarankan individu harus memahami diri mereka sendiri dan sifat pekerjaan dan kemudian menemukan kesesuaian antara kedua faktor ini (Kidd, 2006). Untuk membantu individu untuk menemukan kesesuaian antara diri mereka dan sifat pekerjaan, teori ini mengusulkan bahwa perilaku manusia tergantung pada kepribadian dan lingkungan di dimana orang tersebut hidup dan cara mereka mengekspresikan diri, minat dan nilai-nilai mereka melalui pilihan dan pengalaman kerja (Holland, 1992). Dengan demikian, Holland (1992) telah mengkategorikan individu menjadi enam tipe kepribadian: realistis, investigatif, artistik, sosial, giat dan konvensional dan dia menjelaskan bagaimana tipe kepribadian ini cocok untuk pekerjaan tertentu lingkungan (Sharf, 2002). Misalnya, tipe kepribadian realistis lebih suka terlibat dalam kegiatan atau tugas yang terkait dengan manipulasi sistematis benda, alat, mesin dan binatang, dan tidak perlu bekerja dengan orang lain. Pilihan vokasional yang sesuai untuk realistis tipe kepribadian dapat berhubungan dengan kompetensi mekanik, pertanian atau teknis. Sedangkan tipe kepribadian artistik lebih suka terlibat dalam kegiatan atau tugas yang berhubungan dengan kurang struktur, seperti bahasa, seni, musik dan drama (Holland, 1992).

Enam tipe kepribadian Holland juga merupakan pedoman yang berguna untuk membantu individu memahami kepribadian dan minat vokasional mereka dan memberi mereka kesempatan untuk membuat keputusan pekerjaan yang rasional yang dapat mengarah pada kepuasan karir (Hogan \& Blake, 1999). Misalnya, eksplorasi kepribadian yang dirasakan dan lingkungan kerja pustakawan universitas di Nigeria (Afolabi, 1996) menemukan bahwa mayoritas pustakawan memandang kepribadian mereka sebagai investigatif yang menurut teori Holland, adalah tugas orang yang introspektif dan lebih suka memikirkan sesuatu daripada bertindak secara impulsif. Tipe kepribadian ini tampaknya lebih suka pekerjaan yang terkait dengan penelitian, katalogisasi, klasifikasi dan sebagainya. Yang menarik, pengguna perpustakaan merasakan pustakawan lingkungan kerja membutuhkan orientasi sosial karena pengguna mengharapkan pustakawan untuk melakukannya memiliki kemampuan berkomunikasi dengan baik dengan pengguna perpustakaan. Penelitian menyimpulkan bahwa ketidaksesuaian antara persepsi kepribadian pustakawan dan lingkungan kerja mereka dapat menyebabkan ketidakpuasan kerja. Juga disimpulkan bahwa individu cenderung merasa lebih puas dengan karir mereka ketika mereka memilih lingkungan kerja yang cocok dengan kepribadian dan minat mereka, dan lebih banyak ketidaksesuaian antara lingkungan kerja dan kepribadian dan minat mereka, sehingga mengakibatkan kepuasan karir yang kurang. Studi ini menyoroti dampak hubungan antara kepribadian dan lingkungan kerja pada kepuasan karir individu dan dalam jangka panjang kemungkinan kepuasan karir akan mempengaruhi pengambilan keputusan karir masa depan individu.

Meskipun teori ini muncul berguna untuk membantu orang untuk mengklarifikasi atau menafsirkan minat karier mereka dan pilihan pekerjaan, ada beberapa kelemahan yang terkait dengan aplikasi teori ini. Dikatakan bahwa individu dan lingkungan kerja berinteraksi secara konstan, teori ini berfokus pada pencapaian kecocokan antara orang dan pekerjaan, dan hal tersebut mengabaikan proses yang mempengaruhi keputusan dan pilihan karier individu (Kidd, 2006). Holland (1992) juga mendukung sudut pandang ini seperti yang ia sarankan dalam aplikasi teorinya agar membuat keputusan karier yang efektif. Dimana faktorfaktor lain memengaruhi pilihan karier, termasuk diantaranya adalah usia, gender, kelas sosial 
dan latar belakang pendidikan. Studi sebelumnya juga menunjukkan bahwa validitas struktural dari model tipe kepribadian Holland cenderung memiliki keterbatasan aplikasi dalam beberapa konteks budaya. Misalnya, pemeriksaan kepribadian Holland jenis di antara pria dan wanita muda kulit hitam Afrika Selatan (Toit \& Bruin, 2002) menggunakan analisis penskalaan multidimensi menemukan ketidakcocokan antara data dan model Holland. Dengan demikian, penelitian ini menyimpulkan bahwa model tersebut mungkin tidak dapat diterapkan dalam beberapa konteks budaya, misalnya, di kalangan pemuda Afrika Selatan. Temuan ini juga didukung oleh investigasi menggunakan enam tipe kepribadian Holland di Cina (Leong \& Tracey, 2006). Ini penelitian menyimpulkan bahwa enam tipe kepribadian Belanda lebih relevan dalam konteks barat.

Sementara Holland membantu individu untuk membuat keputusan karir dengan mencocokkan kepribadian mereka dan lingkungan kerja, teori jangkar karir (Career Anchor) Schein fokus pada kesesuaian antara individu kepribadian, kemampuan, dan lingkungan kerja mereka. Schein (1978) mengusulkan konsep jangkar karir untuk memandu keputusan karir individu dan perkembangan karir mereka dalam organisasi. Teori tersebut menekankan bahwa orang cenderung memiliki nilai yang spesifik atau keinginan terhadap pekerjaan mereka di berbagai tahap kehidupan, dan ini mungkin termasuk, untuk misalnya, nilai-nilai dalam kaitannya dengan pekerjaan dan kehidupan mereka serta keterampilan dan kemampuan yang diperlukan untuk lakukan pekerjaan. Schein (1978) mengelompokkan individu dalam hal lima jangkar karir yang berbeda: teknis / kompetensi fungsional, kompetensi manajerial, keamanan dan stabilitas, otonomi dan kemandirian dan kreativitas wirausaha. Kemudian, tiga jangkar selanjutnya diperkenalkan: layanan dan dedikasi untuk menyebabkan, tantangan murni dan gaya hidup (Schein, 1990). Setiap karier jangkar mewakili harapan individu dan kompetensi yang terkait dengan pekerjaan mereka atau karier, yang mendorong keputusan karier mereka. Misalnya, individu dengan keamanan dan stabilitas cenderung membuat keputusan karir berdasarkan keamanan pekerjaan dan tunjangan, sedangkan individu yang menilai otonomi dan independensi cenderung mendasari pengambilan keputusan mereka pada sifat pekerjaan mereka dan apakah itu memungkinkan mereka untuk memiliki kebebasan untuk melakukan tugas-tugas mereka dengan kendala organisasi yang minimal (Schein, 1978).

Konsep jangkar karir tampaknya berguna untuk membantu individu menemukan kesesuaian antara orientasi karir mereka dan lingkungan kerja (Ituma \& Simpson, 2006). Pada saat yang sama, hal ini akan membantu pengusaha untuk menyediakan karyawan dengan lingkungan kerja yang sesuai yang meningkatkan kepuasan karir karyawan dan komitmen terhadap suatu organisasi (Baruch, 2004). Misalnya, investigasi hubungan antara jangkar dan karir lulusan berusaha memahami mengapa lulusan melamar pekerjaan di organisasi besar dan juga menilai kompetensi karir yang mereka rasakan (Stewart \& Knowles, 2000). Pembelajaran menemukan bahwa lulusan melamar pekerjaan di organisasi besar karena mereka menghargai keamanan dan jangkar stabilitas. Mereka juga merasa bahwa organisasi besar akan menyediakannya peluang karir yang lebih baik daripada bisnis kecil. Studi ini menyimpulkan bahwa pada bisnis kecil perekrut harus mempertimbangkan untuk memberi karyawan jalur karir yang jelas dan program pelatihan yang baik untuk membuat posisi di organisasi mereka menarik bagi lulusan baru. Ini studi juga menunjukkan bahwa jangkar karir memberikan organisasi yang lebih baik memahami orientasi karir potensial karyawan dan memungkinkan organisasi untuk mengembangkan strategi yang meningkatkan kepuasan karir karyawan dan komitmen terhadap organisasi.

Meskipun, instrumen jangkar karir Schein tetap bermanfaat bagi individu dan organisasi, namun intsturmen tersebut telah banyak dikritik. Satu kritik adalah bahwa teori itu diperkenalkan pada 1970-an, ketika struktur organisasi sederhana dan linier dan jalur karir dalam suatu organisasi cenderung bergerak dari tingkat operasional ke atas ke tingkat yang lebih tinggi 
(Barukh 2004). Dalam beberapa tahun terakhir, bagaimanapun juga telah dikemukakan bahwa pengembangan karir tidak hanya maju ke atas, tetapi lebih transisi dan dapat bergeser dalam satu fungsi atau lintas fungsi dan tanpa batas (Gilbert, Sohi \& McEachern, 2008). Hasil jangkar individu mungkin tidak statis tetapi dapat berubah melalui berbagai tahap kehidupan mereka (Suutari \& Taka 2004).

Terlepas dari kritik ini, tampaknya tipologi dasar jangkar karir Schein berlanjut menjadi relevan untuk pengembangan karir. Misalnya, studi multikultural baru-baru ini menggunakan jangkar karir untuk menyelidiki dampak perampingan pada rencana karir bisnis pascasarjana siswa di Australia / Selandia Baru, Amerika Serikat, Malaysia, Afrika Selatan, dan Inggris (Marshall \& Bonner, 2003). Studi ini menemukan bahwa jangkar karir relevan dengan para siswa ini. Namun, usia, jenis kelamin, dan budaya adalah prediktor penting bagi karir yang mereka rasakan. Hal ini menunjukkan bahwa usia muncul untuk memprediksi jangkar karir teknis dan fungsional di antara siswa dari Amerika Utara dan Australia / Selandia Baru, sedangkan gender muncul untuk memprediksi jangkar karir yang sama di antara siswa dari Asia. Studi ini juga disorot hubungan antara perampingan dan jangkar karir dan menyarankan bahwa perampingan itu prediktor signifikan kompetensi manajerial pada siswa dari Asia, sedangkan usia adalah prediktor signifikan untuk keamanan dan stabilitas kerja di kalangan siswa dari Australia / Baru Selandia Baru. Studi ini menunjukkan bahwa faktor-faktor seperti usia, jenis kelamin dan budaya memiliki implikasi untuk memprediksi jangkar karir, bagaimanapun, ini tidak mengurangi dari dasar konsep bahwa jangkar karir relevan dengan pengembangan karir dalam organisasi di Indonesia konteks budaya yang berbeda.

Dengan demikian, tipe kepribadian dan lingkungan kerja Holland (1959) dan jangkar karir Schein (1978) telah memberikan pendekatan psikologis yang berguna untuk memahami pengambilan keputusan karir. Pada prinsipnya, teori-teori ini berusaha untuk membantu individu menemukan kesesuaian antara diri mereka sendiri dan lingkungan kerja mereka dan selanjutnya untuk meningkatkan karir mereka kepuasan. Jenis kepribadian dan lingkungan kerja Holland menyoroti karakteristik pekerjaan yang relevan dengan kepribadian dan minat individu. Namun, teorinya mungkin kurang efektif dalam menjelaskan bagaimana individu mengembangkan pengambilan keputusan karier dan tampaknya memiliki aplikasi terbatas pada konteks budaya yang berbeda (Leong \& Tracey 2006). Di sisi lain Sebaliknya, jangkar karir Schein menekankan lingkungan kerja tertentu yang relevan dengan kemampuan dan harapan individu dan tampaknya menjadi pendekatan teoretis yang berguna untuk membantu individu membuat keputusan karier dalam konteks budaya yang berbeda (Marshall \& Bonner 2003).

\section{Pendekatan Sosiologis untuk Pengambilan Keputusan Karir}

Teori pembelajaran sosiologis telah menjadi teori yang paling berpengaruh untuk pengembangan varietas pendekatan sosiologis untuk pengambilan keputusan karir. Teori ini berusaha menjelaskan manusia perilaku dalam hal hubungan antara lingkungan sosial dan cara individu belajar, berperilaku, dan merespons dalam lingkungan sosial tertentu (Abbott, 2001). Teori pembelajaran sosial membentuk landasan teoretis untuk tiga teori utama karier pengambilan keputusan: self-efficacy oleh Bandura (1977), teori pembelajaran sosial tentang pengambilan keputusan karir oleh Krumboltz (1979) dan teori karir kognitif sosial Prapaskah, Brown dan Hackett (1994). Konsep self-efficacy diperkenalkan oleh Albert Bandura pada tahun 1977 ketika ia menggunakan teori sosial untuk menyelidiki perkembangan kepribadian (Prideaux, 2001). Kepribadian berkembang melalui pengalaman belajar dan proses kognitif manusia (Bandura, 1977) dan bahwa pengalaman belajar ini dipengaruhi oleh interaksi tiga kunci faktor (Abbott, 2001). Faktor-faktor ini termasuk faktor individu yang merujuk pada perilaku dan 
faktor lingkungan yang merujuk pada aspek eksternal yang terkait dengan suatu pembelajaran individu. Faktor terakhir, faktor psikologis, mengacu pada proses kognitif terkait dengan bagaimana individu belajar dari konsekuensi interaksi antar faktor individu dan lingkungan, seperti persepsi mereka tentang pengalaman belajar dan pendekatan mereka terhadap pemecahan masalah. Teori pembelajaran sosial Bandura (1977) tentang kepribadian manusia telah menekankan pentingnya proses kognitif manusia dan diperkenalkan aspek kepribadian yang berkembang sebagai hasil dari pengalaman belajar individu. Hal ini adalah pengaturan diri (kemampuan individu untuk menyesuaikan diri dengan keadaan yang berbeda atau lingkungan mereka), harga diri (pandangan individu tentang diri mereka bahagia, percaya diri, tidak aman atau tidak memadai), hukuman diri sendiri (kapasitas seseorang untuk berperilaku negatif dengan mencoba melarikan diri atau melalui ketidakaktifan) dan self-efficacy (Abbott, 2001). Meskipun semua pengaruh ini dipandang penting, konsep self-efficacy telah dianggap sebagai faktor kepribadian kunci yang mempengaruhi pengambilan keputusan karir.

Self-efficacy didefinisikan sebagai keyakinan individu pada kemampuan mereka untuk mengambil tindakan yang diperlukan berurusan dengan tugas yang diberikan atau situasi prospektif (Bandura, 1982). Teori self-efficacy Bandura memberikan pemahaman tentang bagaimana individu mengembangkan self-efficacy dan bagaimana persepsi diri mereka dapat digunakan untuk memprediksi perilaku tertentu (Betz, 2004). Hal ini termasuk apakah individu mendekati atau menghindari tugas atau situasi tertentu, yang kualitas kinerja mereka dengan tugas atau situasi tertentu dan kegigihan mereka untuk mengatasi hambatan atau mengacaukan pengalaman. Misalnya, investigasi terhadap hubungan antara self-efficacy dan aspirasi karir anak - anak dalam lingkungan sosial ekonomi tertentu (Bandura et al. 2001) menemukan bahwa anak-anak cenderung mendasarkan pilihan karir mereka pada self-efficacy yang dirasakan daripada pekerjaan pada kinerja akademik mereka. Temuan ini menunjukkan pengaruh selfefficacy pada pilihan karir dan cara di mana anak-anak cenderung memilih karir yang mereka rasa kompeten untuk dilakukan dan yang dianggap sesuai dengan self-efficacy mereka. Anakanak ini membuat keputusan karir berdasarkan persepsi self-efficacy mereka daripada kinerja akademik mereka dan dipengaruhi oleh kurangnya aspirasi pendidikan orang tua mereka untuk mereka.

Temuan ini didukung oleh investigasi dampak tingkat sosial ekonomi orangtua tentang aspirasi karir di kalangan remaja muda Nigeria (Salami, 2008). Studi ini menyarankan bahwa anak-anak dari keluarga dengan tingkat pendapatan yang tinggi tampaknya memiliki karir yang tinggi aspirasi karena keluarga mereka mampu memberi mereka dukungan akademik yang relevan. Kemungkinan bahwa anak-anak dari latar belakang sosial ekonomi rendah mungkin kurang percaya diri mengembangkan karir mereka melalui pendidikan tinggi dan menyoroti dampak sosial ekonomi lingkungan di jalan anak-anak mengembangkan self-efficacy yang dirasakan pekerjaan mereka. Seperti yang telah dibahas, efikasi diri tampaknya memiliki dampak yang signifikan dalam perjalanan individu memandang minat dan kompetensi karir mereka dan ini selanjutnya mempengaruhi pengambilan keputusan karir mereka. Teori pembelajaran sosial Bandura (1977) tentang manusia kepribadian dan self-efficacy juga telah membentuk landasan teoretis untuk dua lainnya pendekatan teoritis penting untuk pengambilan keputusan karier; Krumboltz (1979) teori pembelajaran sosial pembuatan keputusan karir dan Prapaskah, et.al, (1994) teori karir kognitif sosial.

John D. Krumboltz memperkenalkan 'Teori Pembelajaran Sosial tentang Pembuatan Keputusan Karir'di 1979 dan seperti yang disebutkan sebelumnya, ini adalah pertama kalinya istilah pengambilan keputusan karir menjadi terminologi yang diterima (Brown, 2002). Bandura (1977) menggunakan pembelajaran sosial teori untuk meningkatkan pemahaman orang tentang pengambilan keputusan karir melalui konsep self-efficacy, tetapi teori Krumboltz (1979) 
memasukkan serangkaian pengaruh tambahan di mana seorang individu memiliki sedikit atau tidak ada kontrol. Teori pembelajaran sosial Krumboltz tentang karir pengambilan keputusan mengakui pentingnya dua elemen kunci sosial Bandura teori belajar (Sharf, 2006) bahwa perilaku manusia dihasilkan dari pengalaman belajar (aksi) dan kognisi (mengetahui atau berpikir). Teori Kromboltz menekankan, bagaimanapun, bahwa keputusan karir tidak hanya didasarkan pada faktor individu seperti jenis kelamin, usia, latar belakang pendidikan, kemampuan dan latar belakang keluarga tetapi pada faktor-faktor penting lainnya kontrol individu luar, yang memengaruhi ketersediaan karir dan pengambilan keputusan karier mereka (Mitchell \& Krumboltz, 1996). Misalnya, sifat peluang kerja, imbalan moneter dan sosial dari berbagai pekerjaan, hukum perburuhan dan aturan serikat pekerja, perkembangan teknologi, perubahan organisasi sosial (misalnya kesejahteraan), sistem pendidikan dan pengaruh lingkungan dan masyarakat dapat memiliki yang penting berdampak pada pengambilan keputusan karir. Dengan demikian, Krumboltz menerapkan pendekatan pembelajaran sosial yang berfokus pada peran empat pengaruh besar pada pengambilan keputusan karir individu (Patton \& McMahon, 1999). Faktor - faktor tersebut yakni faktor individu (jenis kelamin, kemampuan, keterampilan, sifat kepribadian, dan keluarga latar belakang), faktor lingkungan (budaya, persyaratan pekerjaan dan pendidikan), hubungan antara keterampilan dan tugas pekerjaan (sesuai dengan kebutuhan individu untuk pekerjaan) dan pengalaman pembelajaran karir (dampak dari individu belajar tentang pengambilan keputusan karir mereka). Hal ini menyoroti hubungan antara keyakinan individu dan lingkungan serta bagaimana hal ini memengaruhi pendekatan individu mempelajari keterampilan baru dan pada akhirnya memengaruhi aspirasi dan tindakan mereka. Misalnya seseorang mungkin memiliki bakat musik, namun, kurangnya dukungan finansial atau terbatasnya keluarga akses ke pelatihan musik dapat memengaruhi keputusan karirnya untuk menjadi seorang musisi (Patton \& McMahon 1999).

Keterkaitan di antara keempat faktor ini telah ditunjukkan secara studi kuantitatif, yang menggunakan teori pembelajaran sosial Krumboltz (1979) tentang pembuatan keputusan karir mengidentifikasi faktor-faktor yang terkait dengan pilihan karir di kalangan mahasiswa pertanian perkotaan (Esters \& Bowen, 2004). Studi ini menemukan bahwa orang tua dan teman-teman memiliki pengaruh signifikan terhadap keputusan untuk mendaftar di kursus tetapi minat pribadi, pengalaman belajar selama kursusdan peluang karir di bidang pertanian dianggap memengaruhi karir keputusan selanjutnya. Studi ini menyarankan bahwa teori itu berguna untuk mengidentifikasi faktor-faktor yang relevan terkait dengan latar belakang keluarga siswa, dampak dari pengalaman belajar mereka dan faktor-faktor yang memfasilitasi karir mereka. Bagaimanapun, bahwa studi kualitatif yang mendalam harus dilakukan untuk menghasilkan lebih banyak faktor dan mendapatkan pemahaman yang lebih baik tentang interaksi faktor-faktor yang mempengaruhi siswa pertanian perkotaan. Rekomendasi ini mungkin terkait dengan fakta bahwa teori tersebut mendekati pengambilan keputusan karir individu dengan mengidentifikasi berbagai faktor yang mempengaruhi pengambilan keputusan karir mereka. Namun, hal tersebut tidak memberikan pemahaman tentang keterkaitan faktor-faktor ini atau bagaimana dampak akan proses pengambilan keputusan karir individu. Karena itu, nilai yang mendalam pada studi kualitatif adalah bahwa hal itu akan memungkinkan faktor tambahan untuk muncul dan akan memberikan pemahaman yang lebih baik tentang bagaimana faktor-faktor ini saling terkait dan bagaimana pengaruhnya pembuatan keputusan karir individu.

Seperti yang telah ditunjukkan, teori pembelajaran sosial Krumboltz (1979) tentang pengambilan keputusan karir adalah pendekatan yang berguna untuk memahami bagaimana individu membuat keputusan dan indikasi karir bagaimana pengetahuan ini dapat digunakan untuk membantu individu menghasilkan karir alternatif dan membuat 
keputusan karir yang efektif dalam situasi yang berbeda (Sharf, 2006). Namun sedikit sekali studi empiris yang telah meneliti teori ini. Satu penjelasan untuk ini adalah bahwa teori dikembangkan untuk tujuan konseling karir dan untuk memberikan pedoman untuk konselor karir yang bekerja dengan klien mereka. Teori Krumboltz (1979) telah digunakan untuk membantu klien mengeksplorasi keterampilan, minat, kepercayaan, nilai-nilai dan kepribadian mereka serta mendorong karir intervensi untuk membantu klien dengan strategi untuk pengembangan karir mereka (Swanson \& Fouad, 1999). Teori karir kognitif sosial berusaha menjelaskan bagaimana individu membuat keputusan karir dengan mempertimbangkan hubungan antara individu (faktor internal) dan faktor lingkungan (faktor eksternal) yang memengaruhi pembelajaran, self-efficacy seseorang dan minat karir (Sharf, 2006). Teori ini menekankan interaksi pembelajaran pengalaman, self-efficacy dan ekspektasi hasil dan cara ini mempengaruhi individu minat karir dan pilihan mereka. Disarankan bahwa pengalaman belajar mempengaruhi cara individu mengembangkan self-efficacy dan harapan hasil yang dirasakan (yaitu konsekuensi tindakan, tujuan atau tugas tertentu), sedangkan interaksi antara self-efficacy dan ekspektasi hasil mempengaruhi minat dan pilihan karir individu.

Teori ini juga menunjukkan pentingnya memahami dampak pada variabel self-efficacy latar belakang seperti keluarga, kelas sosial, jenis kelamin, etnis dan pembelajaran pengalaman, yang mencakup sifat dan kualitas peluang pendidikan (Kidd, 2006). Misalnya, penyelidikan hubungan antara identitas etnis, pengambilan keputusan karir, dan harapan pekerjaan di kalangan siswa sekolah menengah Latino di AS timur laut (Gushue, 2006) menunjukkan bahwa etnis memiliki pengaruh kuat terhadap keyakinan mengenai kemampuan mereka untuk mencari karier (self-efficacy) tetapi tidak secara langsung mempengaruhi mereka harapan pekerjaan. Studi ini menunjukkan bahwa para siswa ini tampaknya mengembangkan kemampuan mereka pengambilan keputusan karier dalam hal self-efficacy mereka karena kemungkinan semakin banyak mereka mencapai tugas atau sasaran mereka (self-efficacy), semakin percaya diri yang mereka kembangkan dalam hal pengambilan keputusan karier mereka.

Sebuah studi tentang siswa sekolah menengah di Australia (Roger, Creed \& Glendon, 2008) menemukan bahwa kepribadian mempengaruhi pengembangan self-efficacy individu, sedangkan dukungan sosial (keluarga dan teman) memengaruhi sasaran karir dan pengambilan keputusan. Seperti yang telah ditunjukkan dalam penelitian ini, teori karir kognitif sosial tampaknya bermanfaat untuk mendapatkan pemahaman yang lebih baik tentang proses pengambilan keputusan karir individu. Hal ini memungkinkan berbagai faktor yang terkait dengan proses pengambilan keputusan karier diidentifikasi dan memberikan penjelasan konstruktif tentang bagaimana faktor-faktor ini saling terkait dan selanjutnya dapat mengarah pada pengambilan keputusan dan pilihan karir. Dan yang terpenting, pendekatan ini relevan dengan berbagai konteks budaya yang berbeda.

\section{METODE}

\section{Pendekatan Penelitian}

Penelitian ini akan menggunakan pendekatan penelitian deskriptif kualitatif. Tujuan penelitian dengan metoda deskriptif adalah mengungkapkan kejadian atau fakta, keadaan, fenomena, variabel dan keadaan yang terjadi, saat penelitian berlangsung dengan menuliskan apa yang sebenarnya terjadi. Menurut Nazir (1988), metoda deskriptif ini lebih merupakan suatu metoda yang meneliti status kelompok manusia, suatu objek, suatu set kondisi, suatu sistem pemikiran atau suatu kumpulan peristiwa pada masa sekarang. Sedangkan menurut Sugiyono (2005), metoda deskriptif adalah suatu metoda yang digunakan untuk menggambarkan atau menganalisis suatu hasil penelitian. Sedangkan menurut Bungin (2010), penelitian social menggukan format deskriptif kualitatif bertujuan untuk mengkritik kelemahan penelitian 
kuantitatif (yang terlalu positivism) serta juga bertujuan untuk menggambarkan, meringkaskan berbagai kondisi, berbagai situasi, dan berbagai fenomena realitas sosial yang ada di masyarakat yang menjadi objek penelitian, dan berupaya menarik realitas itu ke permukaan sebagai suatu ciri, karakter, sifat, model, tanda atau gambaran tentang kondisi, situasi, ataupun fenomena tertentu. Kemudian, tujuan dari dilakukannya metoda penelitian deskriptif kualitatif adalah tidak hanya untuk menjelaskan secara menyeluruh masalah yang akan diteliti dan diamati saja, namun juga tujuan lainnya. Tujuan yang dimaksud adalah menjadi pedoman pelaksanaan penelitian.

\section{Metode Pengumpulan Data}

Penelitian akan dilakukan dengan cara menyebarkan kuisoner kepada mahasiswa S1 Akuntansi Sekolah Tinggi Ilmu Ekonomi Indonesia (STIESIA) Surabaya yang telah menempuh mata kuliah Sistem Informasi Akuntansi dan sedang menempuh mata kuliah penulisan Skripsi. Responden akan dimintai data melalui sebuah daftar pertanyaan. Responden diminta untuk merespon pentingnya beberapa item menggunakan skala peringkat terperinci (itemized rating scale), untuk beberapa item dengan menjawab pilihan mereka. Menurut Sekaran dan Bougie (2009), penggunaan skala peringkat terperinci ini disediakan untuk setiap item dan responden menyatakan angka yang sesuai di setiap item atau melingkari angka yang relevan di setiap item.

\section{Teknik Analisis Data}

Instrumen penelitian diadopsi dari Walstrom et.al (2008) dengan modifikasi sesuai dengan kondisi di Indonesia. Evaluasi harus dilakukan sesuai dengan jawaban yang diberikan. Analisis dilakukan dengan cara deskriptif teknik analisis. Analisis ini digunakan untuk cari dan buat kesimpulan dari temuan itu dapat ditemukan di lapangan. Temuan itu dikumpulkan kemudian disajikan dalam tabulasi atau grafik untuk membuatnya lebih mudah dimengerti atau dibaca.

\section{HASIL DAN PEMBAHASAN}

Penelitian ini untuk mengeksplor faktor-faktor yang menentukan mahasiswa akuntansi di STIESIA Surabaya dalam memilih atau tidak memilih karir dibidang Sistem Informasi Akuntansi dengan menyebarkan kuesioner kepada mahasiswa yang telah menempuh mata kuliah sistem informasi akuntansi. Kuesioner yang disebarkan kepada responden sebanyak 100 dan kembali sejumlah 96 kuesioner. Kemudian diproses untuk dilakukan analisis data berdasarkan statistik deskriptif yang dapat dijelaskan sebagai berikut:

1. Berdasarkan Gender

Berdasarkan proses analisis data deksriptif berdasarkan gender sebagaimana tersaji dalam tabel 1 menunjukkan jumlah responden laki-laki sebesar 7 mahasiswa atau sebanyak $(7,3 \%)$ dan responden perempuan sebesar 89 mahasiswa atau (92,7\%). Artinya responden kebanyakan adalah perempuan.

\section{Tabel 1}

\begin{tabular}{|c|c|c|c|c|c|}
\hline \multicolumn{6}{|c|}{ karakteristik Responden berdasarkan Gender } \\
\hline & & Frequency & Percent & $\begin{array}{c}\text { Valid } \\
\text { Percent }\end{array}$ & $\begin{array}{c}\text { Cumulative } \\
\text { Percent }\end{array}$ \\
\hline \multirow[t]{3}{*}{ Valid } & Laki-Laki & 7 & 7.3 & 7.3 & 7.3 \\
\hline & Perempuan & 89 & 92.7 & 92.7 & 100.0 \\
\hline & Total & 96 & 100.0 & 100.0 & \\
\hline
\end{tabular}

Sumber: Data primer yang telah diolah, 2020 


\section{Berdasarkan minat konsentrasi}

Berdasarkan analisis statistik deskriptif untuk pilihan minat konsentrasi dari 96 responden sebagaimana tersaji pada tabel 2 menunjukkan minat konsentrasi Akuntansi Keuangan berjumlah 49 mahasiswa atau sekitar 51\%, minat kosentrasi Akuntansi Sektor Publik berjumlah 44 mahasiswa atau sekitar 45,8\% dan minat konsentrasi Akuntansi Manajemen berjumlah 3 mahasiswa atau sekitar 3,1\%. Artinya minat konsentrasi responden didominasi pada Akuntansi keuangan dan Akuntansi Sektor Publik.

Tabel 2

\begin{tabular}{|l|l|r|r|r|r|}
\hline \multicolumn{7}{|c|}{ Minat Konsentrasi } \\
\hline \multirow{3}{*}{ Valid } & Frequency & Percent & $\begin{array}{c}\text { Valid } \\
\text { Percent }\end{array}$ & $\begin{array}{c}\text { Cumulative } \\
\text { Percent }\end{array}$ \\
\cline { 2 - 6 } & Akuntansi Keuangan & 49 & 51.0 & 51.0 & 51.0 \\
\cline { 2 - 7 } & Akuntansi Sektor Publik & 44 & 45.8 & 45.8 & 96.9 \\
\cline { 2 - 7 } & Akuntansi Manajemen & 3 & 3.1 & 3.1 & 100.0 \\
\cline { 2 - 6 } & Total & 96 & 100.0 & 100.0 & \\
\hline
\end{tabular}

Sumber: Data primer yang telah diolah, 2020

3. Komputer merupakan alat penting mendukung karir

Berdasarkan Analisis Statisitik deskriptif sebagaiamana tersaji pada tabel 3 dari 96 respoden saat ditanya apakah komputer alat penting mendukung, kebanyakan responden menjawab ya sebanyak 94 mahasiswa atau sebanyak 97,9\% dan yang menjawab tidak hanya 2 mahasiswa atau 2,1\%. Artinya responden sangat setuju komputer sebagai alat mendukung karir.

\section{Tabel 3}

\begin{tabular}{|l|r|r|r|r|r|}
\hline \multicolumn{7}{|c|}{ Komputer alat Penting Mendukung karir } \\
\hline \multirow{2}{*}{ Valid } & Ya & Frequency & Percent & $\begin{array}{c}\text { Valid } \\
\text { Percent }\end{array}$ & $\begin{array}{c}\text { Cumulative } \\
\text { Percent }\end{array}$ \\
\cline { 2 - 7 } & Tidak & 94 & 97.9 & 97.9 & 97.9 \\
& Total & 2 & 2.1 & 2.1 & 100.0 \\
\hline
\end{tabular}

Sumber: Data primer yang telah diolah, 2020

4. $\quad$ Karir yang diinginkan setelah lulus

Berdasarkan analisis statistik deskriptif, jawaban 96 responden tentang pekerjaan yang diinginkan setelah lulus sebagaimana tersaji pada tabel 4. Ada 4 pilihan jawaban yang tersedia dan jawaban pilihan jawaban tertinggi tentang karir yang dinginkan setelah lulus adalah (1) Sistem informasi Akuntansi sebanyak 43 responden atau sekitar 44.8\%, (2) Akuntansi Pemerintahan sebanyak 40 mahasiswa atau sebesar 41,7\%, (3) Akuntansi Manajemen sebanyak 8 mahasiswa atau sekitar 8,3\% dan (4) Karir dibidang Auditor Independen berjumlah 5 mahasiwa atau sekitar 5,2\%. Artinya pilihan karir mahasiswa setelah lulus didominasi pada Karir dibidang Sistem Informasi Akuntansi dan Akuntansi Pemerintahan: 
Tabel 4

\begin{tabular}{|l|l|r|r|r|r|}
\hline \multicolumn{6}{|c|}{ Pekerjaan yang diinginkan setelah lulus } \\
\hline \multirow{3}{*}{ Valid } & Frequency & Percent & $\begin{array}{c}\text { Valid } \\
\text { Percent }\end{array}$ & $\begin{array}{c}\text { Cumulative } \\
\text { Percent }\end{array}$ \\
\cline { 2 - 6 } & Sistem Informasi Akuntansi & 43 & 44.8 & 44.8 & 44.8 \\
\cline { 2 - 6 } & Akuntansi Manajemen & 8 & 8.3 & 8.3 & 53.1 \\
\cline { 2 - 6 } & Akuntansi Pemerintahan & 40 & 41.7 & 41.7 & 94.8 \\
\cline { 2 - 7 } & Auditor Independen & 5 & 5.2 & 5.2 & 100.0 \\
\cline { 2 - 6 } & Total & 96 & 100.0 & 100.0 & \\
\hline
\end{tabular}

Sumber: Data primer yang telah diolah, 2020

5. Ketertarikan Pekerjaan di bidang Sistem Informasi Akuntansi

Berdasarkan hasil analisis statistik deskriptif sebagaiamana tersaji pada tabel 5, dari 96 responden ditanya ketertarikan Pekerjaan di bidang Sistem Informasi Akuntansi, maka Responden yang menjawab "ya" sebanyak 73 mahasiswa atau sebesar $76 \%$ dan yang menjawab "tidak" sebanyak 23 mahasiswa atau sekitar 24\%. Artinya sebenarnya mahasiswa tertarik untuk bekerja di bidang Sistem Informasi Akuntansi.

Tabel 5

\begin{tabular}{|l|l|r|r|r|r|}
\hline \multicolumn{7}{|c|}{ Ketertarikan Pekerjaan di bidang S IA } \\
\hline Valid & Ya & Frequency & Percent & $\begin{array}{c}\text { Valid } \\
\text { Percent }\end{array}$ & $\begin{array}{c}\text { Cumulative } \\
\text { Percent }\end{array}$ \\
\cline { 2 - 7 } & Tidak & 73 & 76.0 & 76.0 & 76.0 \\
& Total & 23 & 24.0 & 24.0 & 100.0 \\
\hline
\end{tabular}

Sumber: Data primer yang telah diolah, 2020

6. Faktor yang mendasari ketertarikan Pekerjaan SIA

Berdasarkan hasil analisis statistik deskriptif sebagaimana tersaji pada tabel 6. Ada delapan faktor penting bagi mahasiswa ketertarikannya pekerjaan di bidang Sistem Informasi akuntansi (SIA), yaitu: (1) Saran Dosen, (2) Saran Dosen Pembimbing Skripsi, (3) Mudah Memahami SIA, (4) Materi Perkuliahan SIA menarik, (5) Minat SIA, (6) Pengaruh Keluarga, (7) Saran dari Teman, (8) Gaji Tinggi. Berdasarkan penilaian interval kelas dari sangat tidak penting sampai sangat penting (1-5) yang dikategorikan dalam 5 interval kelas sebagai berikut:

1. Sangat tidak penting $(1<1,8)$

2. Tidak penting $(1,8<2,6)$

3. Cukup penting $(2,6<3,4)$

4. Penting $(3,4<4,2)$

5. Sangat Penting $(4,2<5)$

Berdasarkan tabel 6 tentang nilai rata-rata faktor-faktor yang menentukan ketertarikan Pekerjaan di Bidang SIA maka dapat dijelaskan sebagai berikut: 
1. Faktor Saran Dosen dengan nilai rata-rata 4.2740 terletak pada interval kelas sangat penting. Artinya ketertarikan pada pekerjaan SIA saran dosen menjadi hal penting yang dipertimbangkan oleh mahasiswa

2. Saran Dosen Pembimbing Skripsi.Saran Dosen dengan nilai rata-rata 4.3425 terletak pada interval kelas sangat penting. Artinya ketertarikan mahasiswa pada pekerjaan SIA, Saran Dosen Pembimbing menjadi hal sangat penting dipertimbangan mahasiswa.

3. Mudah Memahami SIA. Mudah memahami SIA dengan nilai rata-rata 4.4247 terletak pada interval kelas "sangat penting". Artinya, Mudah memahami SIA menjadi pertimbangan sangat penting mahasiswa ketertarikan pada pekerjaan dibidang SIA

4. Materi Perkuliahan SIA Menarik Materi Perkuliahan SIA menarik memiliki nilai rata-rata 3.8219 yang terletak pada interval kelas "penting". Artinya Materi perkuliahan SIA menarik menjadi pertimbangan penting mahasiswa ketertarikan pekerjaan di bidang SIA

5. Minat SIA.Minat SIA memiliki nilai rata-rata 4.0137 yang terletak pada interval kelas penting. Artinya Minat SIA penting menjadi pertimbangan Mahasiswa pada ketertarikan pekerjaan pada bidang SIA.

6. Pengaruh Keluarga. Pengaruh Keluarga memiliki nilai rata-rata 3.8219 yang terletak pada interval kelas kategori "penting", artinya pengaruh keluarga penting dipertimbangkan mahasiswa dalam ketertarikan pekerjaan dibidang SIA.

7. Saran dari Teman, saran dari teman memiliki nilai rata-rata 3.6712 yang terletak pada interval kelas penting. Artinya Saran dari teman menjadi salah satu pertimbangan mahasiswa dalam menentukan ketertarikan di bidang SIA.

8. Gaji Tinggi, Gaji Tinggi memiliki nilai 4.0274 yang terletak nilainya pada interval kelas sangat penting. Artinya Gaji yang tinggi menjadi pertimbangan mahasiswa dalam ketertarikan mahasiswa dalam pekerjaan dibidang SIA.

Artinya dari delapan faktor jawaban Respoden yang sangat penting dan penting dalam mendukung Pekerjaan dibidang SIA adalah (1) Memahami di bidang SIA, (2) Saran Dosen Pembimbing Skripsi, (3) Saran Dosen, (4) Minat terhadap SIA, (5) Gaji tinggi.

\section{Tabel 6}

Faktor-Faktor yang memengaruhi karir dibidang SIA

\begin{tabular}{|l|r|r|r|r|r|}
\hline & $\mathrm{N}$ & Minimum & Maximum & \multicolumn{1}{c|}{ Mean } & $\begin{array}{c}\text { Std. } \\
\text { Deviation }\end{array}$ \\
\hline Saran Dosen & 73 & 3.00 & 5.00 & 4.2740 & .71220 \\
Saran Dosen Pembimbing Skripsi & 73 & 2.00 & 5.00 & 4.3425 & .74943 \\
Mudah Memahami SIA & 73 & 3.00 & 5.00 & 4.4247 & .70549 \\
Materi Perkuliahan SIA menarik & 73 & 3.00 & 5.00 & 3.8219 & .71380 \\
Minat SIA & 73 & 3.00 & 5.00 & 4.0137 & .71673 \\
Pengaruh Keluarga & 73 & 2.00 & 5.00 & 3.8219 & .82230 \\
Saran dari Teman & 73 & 2.00 & 5.00 & 3.6712 & .72753 \\
Gaji Tinggi & 73 & 3.00 & 5.00 & 4.0274 & .76326 \\
& 73 & & & & \\
\hline
\end{tabular}

Sumber: Data primer yang telah diolah, 2020 


\section{Faktor-Faktor Ketidaktertarikan mahasiswa berkarir di bidang SIA}

Responden yang tidak tertarik berkarir dibidang SIA sebanyak 23 Mahasiswa dari Total Responden 96 atau hanya $24 \%$ nya saja. Ada delapan faktor yang tersedia untuk di jawab responden ketidaktarikan karir dibidang sistem informasi Akuntansi, yaitu: (1) Dosen SIA membosankan, (2) Dosen SIA tidak menarik, (3) Materi SIA sangatlah Sulit, (4) Kesempatan berkarir di SIA tidak menjanjikan, (5) bidang SIA adalah bidang karir yang saya hindari, (6) Gaji di SIA tidak tinggi, (7) Saya tidak merasa cocok dengan Pekerjaan di bidang SIA, (8) Pekerjaan di bidang SIA tidak prestisius. Ternyata hanya ada 3 jawaban yang dipilih responden, yaitu: (1) materi SIA sulit (8,3\%), (2) Kesempatan berkarir tidak menjanjikan (4,2\%), (3) Tidak merasa cocok (87,5\%). Artinya dari ketiga pilihan jawaban Responden ketidak tertarikan berkarir di bidang SIA yang paling besar adalah Tidak merasa cocok bekerja di bidang SIA.

\section{Tabel 7}

Faktor ketidaktertarikan mahasiswa di bidang SIA

\begin{tabular}{|c|c|c|c|c|c|}
\hline \multicolumn{6}{|c|}{ Ketidak tertarikan memilih Karir SIA } \\
\hline & & Frequency & Percent & $\begin{array}{c}\text { Valid } \\
\text { Percent }\end{array}$ & $\begin{array}{c}\text { Cumulative } \\
\text { Percent }\end{array}$ \\
\hline \multirow[t]{4}{*}{ Valid } & Materi SIA Sulit & 2 & 2.1 & 8.3 & 8.3 \\
\hline & Kesempatan berkarir tidak menjanjikan & 1 & 1.0 & 4.2 & 12.5 \\
\hline & Tidak Merasa cocok & 21 & 21.9 & 87.5 & 100.0 \\
\hline & Total & 24 & 25.0 & 100.0 & \\
\hline Missing & Sy stem & 72 & 75.0 & & \\
\hline \multicolumn{2}{|l|}{ Total } & 96 & 100.0 & & \\
\hline
\end{tabular}

Sumber: Data primer yang telah diolah, 2020

\section{Pembahasan}

Berdasarkan hasil analisis deskriptif seperti yang telah diuraikan sebelumnya, maka berikut ini akan dibahas tentang pilihan karir mahasiswa dibidang sistem informasi akuntansi atau tidak memilih.

1. Ketertarikan memilih pekerjaan dibidang Sistem Informasi Akuntansi

Berdasarkan tabel 8 menunjukkan dari 73 respoden yang tertarik pekerjaan di bidang akuntansi berdasarkan (1) gender didominasi perempuan yaitu sebesar 68 mahasiswa atau $93.2 \%$ dan lakilaki 5 mahasiswa atau 6.8\% saja. (2) Minat Konsentrasi: Akuntansi keuangan 41 mahasiswa atau $56.2 \%$, Akuntansi sektor publik 31 mahasiswa atau $42.5 \%$ dan Akuntansi Manajemen 1 mahasiswa atau $1.3 \%$ saja. (3) Komputer alat penting dalam mendukung karir 71 mahasiswa atau 97.3\% dan 2 orang menyatakan tidak penting atau 2.7\% saja. Artinya Komputer menjadi alat penting dalam mendukung karir. (4) Pekerjaan yang diinginkan setelah lulus, yaitu Sistem Informasi Akuntansi 43 Mahasiswa atau 58.9\%, Akuntansi Manajemen 2 mahasiswa atau 2.7\%, Akuntansi Pemerintah 27 Mahasiswa atau 37\% dan di Auditor Independen 1 Mahasiswa atau 1.4\%. Artinya Dominasi pekerjaan yang diinginkan setelah lulus adalah pada bidang Sistem Informasi Akuntansi dan Akuntansi Pemerintah. 
Tabel 8

Karakteristik Responden tertarik di Bidang SIA

\begin{tabular}{|c|c|c|c|}
\hline \multicolumn{2}{|r|}{ Karakteristik Responden } & $\begin{array}{c}\text { Jumlah } \\
\text { Resnonden }\end{array}$ & $\begin{array}{c}\text { Persentase } \\
(\%)\end{array}$ \\
\hline 1 & $\begin{array}{ll} & \text { Gender } \\
\text { a. } & \text { Laki-laki } \\
\text { b. } & \text { Perempuan }\end{array}$ & $\begin{array}{c}5 \\
68\end{array}$ & $\begin{array}{c}6.8 \\
93.2\end{array}$ \\
\hline 2 & $\begin{array}{l}\text { Minat Konsentrasi } \\
\text { a. } \quad \text { Akuntansi Keuangan } \\
\text { b. } \quad \text { Akuntansi Sektor Publik } \\
\text { c. }\end{array}$ & $\begin{array}{c}41 \\
31 \\
1\end{array}$ & $\begin{array}{c}56.2 \\
42.5 \\
1.3\end{array}$ \\
\hline 3 & $\begin{array}{l}\text { Komputer penting mendukung karir } \\
\text { a. } \quad \text { Ya } \\
\text { b. } \quad \text { Tidak }\end{array}$ & $\begin{array}{c}71 \\
2\end{array}$ & $\begin{array}{c}97.3 \\
2.7\end{array}$ \\
\hline 4 & Ketertarikan pekerjaan di SIA & 73 & 100 \\
\hline 5 & \begin{tabular}{ll}
\multicolumn{2}{l}{ Karir yang diinginkan setelah lulus } \\
a. & Sistem informasi Akuntansi \\
b. & Akuntansi Manajemen \\
c. & Akuntansi Pemerintahan \\
d. & Auditor Independen
\end{tabular} & $\begin{array}{c}43 \\
2 \\
27 \\
1\end{array}$ & $\begin{array}{c}58.9 \\
2.7 \\
37 \\
1.4\end{array}$ \\
\hline
\end{tabular}

Sumber: Data primer yang telah diolah, 2020

Meskipun dari karakteristik respoden yang tertarik pekerjaan di bidang SIA misalkan pada minat konsentrasi tidak mendukung terhadap karir. Akan tetapi ternyata keinginan mahasiswa masih tinggi untuk berkarir dibidang Sistem Informasi Akuntansi, yaitu 58.9\% dibandingkan dengan Karir dibidang lainnya seperti Akuntansi Manajemen 2.7\%, Akuntansi Pemerintah $37 \%$ dan Auditor Independen 1.4\%. Hal ini berarti terdapat peluang bagi STIESIA surabaya untuk membuka konsentrasi yang mendukung pada karir di bidang Sistem Informasi Akuntansi. Langkah yang dapat diambil adalah dengan mempersiapkan kurikulum baru dan menyiapkan infrastruktur baik hardware maupun software dan yang paling penting adalah menyiapkan dosen yang professional di bidang Sistem Informasi Akuntasi tidak hanya secara konsep tetapi juga secara praktis. 
Tabel 9

\begin{tabular}{|l|r|r|r|r|r|}
\hline \multicolumn{7}{|c|}{ Faktor-Faktor yang memengaruhi karir dibidang SIA } \\
\hline & $\mathrm{N}$ & Minimum & Maximum & Mean & \multicolumn{1}{c|}{$\begin{array}{c}\text { Std. } \\
\text { Deviation }\end{array}$} \\
\hline Saran Dosen & 73 & 3.00 & 5.00 & 4.2740 & .71220 \\
Saran Dosen Pembimbing Skripsi & 73 & 2.00 & 5.00 & 4.3425 & .74943 \\
Mudah Memahami SIA & 73 & 3.00 & 5.00 & 4.4247 & .70549 \\
Materi Perkuliahan SIA menarik & 73 & 3.00 & 5.00 & 3.8219 & .71380 \\
Minat SIA & 73 & 3.00 & 5.00 & 4.0137 & .71673 \\
Pengaruh Keluarga & 73 & 2.00 & 5.00 & 3.8219 & .82230 \\
Saran dari Teman & 73 & 2.00 & 5.00 & 3.6712 & .72753 \\
Gaji Tinggi & 73 & 3.00 & 5.00 & 4.0274 & .76326 \\
Valid N (listwise) & 73 & & & & \\
\hline
\end{tabular}

Sumber: Data primer yang telah diolah, 2020

Berdasarkan tabel 9 yang menunjukkan faktor-faktor yang penting memengaruhi karir dibidang Sistem Informasi Akuntansi adalah (1) Mudah memahami SIA, (2) Saran Dosen Pembimbing Skripsi, (3) Saran Dosen, (4) Gaji tinggi, (5) Minat di bidang SIA, yang nilai ratarata diatas 4 yang berarti menurut responden 5 faktor tersebut yang menjadi pertimbangan yang sangat penting menentukan karir dibidang Sistem Informasi Akuntansi. Hal ini menunjukkan bahwa dosen tetap menjadi rujukan utama mahasiswa dalam menentukan pilihan karir di bidang SIA selain kemampuan konsep memahami SIA.

2. Ketidaktertarikan memilih pekerjaan dibidang Sistem Informasi Akuntansi karakteristik Responden yang tidak tertarik karir dibidang Sistem Informasi Akuntansi seperti tersaji dalam tabel 10 berikut:

Tabel 10

Karakteristik Responden tidak tertarik berkaris di Bidang SIA

\begin{tabular}{|c|c|c|c|}
\hline \multicolumn{2}{|r|}{ Karakteristik Responden } & Jumlah & $\begin{array}{c}\text { Persentase } \\
(\%)\end{array}$ \\
\hline 1 & $\begin{array}{ll} & \text { Gender } \\
\text { a. } & \text { Laki-laki } \\
\text { b. } & \text { Perempuan }\end{array}$ & $\begin{array}{c}2 \\
21\end{array}$ & $\begin{array}{c}8.7 \\
91.3\end{array}$ \\
\hline 2 & $\begin{array}{l}\text { Minat Konsentrasi } \\
\text { a. } \quad \text { Akuntansi Keuangan } \\
\text { b. } \quad \text { Akuntansi Sektor Publik } \\
\text { c. } \quad \text { Akuntansi Manajemen }\end{array}$ & $\begin{array}{c}8 \\
13 \\
2\end{array}$ & $\begin{array}{c}34.8 \\
56.5 \\
8.7\end{array}$ \\
\hline
\end{tabular}




\begin{tabular}{|c|c|c|c|}
\hline 3 & $\begin{array}{l}\text { Komputer penting mendukung karir } \\
\text { a. } \quad \text { Ya } \\
\text { b. } \quad \text { Tidak }\end{array}$ & $\begin{array}{c}23 \\
0\end{array}$ & $\begin{array}{c}100 \\
0\end{array}$ \\
\hline 4 & Ketertarikan pekerjaan di SIA & 73 & 100 \\
\hline 5 & $\begin{array}{l}\text { Karir yang diinginkan setelah lulus } \\
\text { a. } \quad \text { Sistem informasi Akuntansi } \\
\text { b. } \quad \text { Akuntansi Manajemen } \\
\text { c. } \quad \text { Akuntansi Pemerintahan } \\
\text { d. } \quad \text { Auditor Independen }\end{array}$ & $\begin{array}{c}0 \\
6 \\
13 \\
4\end{array}$ & $\begin{array}{c}0 \\
26.1 \\
56.5 \\
17.4\end{array}$ \\
\hline
\end{tabular}

Sumber: Data primer yang telah diolah, 2020

Berdasarkan tabel 10 menunjukkan dari 23 respoden yang tidak tertarik pekerjaan di bidang akuntansi berdasarkan (1) gender didominasi perempuan yaitu sebesar 21 mahasiswa atau 91.3\% dan laki-laki 2 mahasiswa atau 8.7\% saja. (2) Minat Konsentrasi: Akuntansi keuangan 8 mahasiswa atau 34.8\%, Akuntansi sektor publik 13 mahasiswa atau 56.5\% dan Akuntansi Manajemen 2 mahasiswa atau $8.7 \%$ saja. (3) Komputer alat penting dalam mendukung karir 23 mahasiswa atau $100 \%$ Artinya Komputer menjadi alat penting dalam mendukung karir. (4) Pekerjaan yang diinginkan setelah lulus, yaitu Sistem Informasi Akuntansi 0 Mahasiswa atau 0\%, Akuntansi Manajemen 6 mahasiswa atau 26.1\%, Akuntansi Pemerintah 13 Mahasiswa atau 56.5\% dan di Auditor Independen 4 Mahasiswa atau 17.4\%. Artinya Dominasi pekerjaan yang diinginkan setelah lulus adalah pada bidang Akuntansi pemerintah. Hal ini berarti Responden yang tidak tertarik pekerjaan di bidang SIA setelah lulus tetap konsisten bekerja diluar SIA.

Berdasarkan tabel 11 yang menjadi ketidaktertarikan Mahasiswa pekerjaan di bidang SIA adalah 2 jawaban penting, yaitu Materi SIA sulit 2 Mahasiswa atau $8.7 \%$ dan Tidak merasa cocok bekerja di bidang SIA 21 mahasiswa atau 91.3\%. hal ini menunjukkan bahwa tidak merasa cocok karir di bidang SIA dan Materi SIA Sulit. karena tidak memiliki latar belakang keilmuan di bidang SIA dikarenakan minat konsentrasi di STIESIA hanya ada tiga bidang, yakni: (1) Akuntansi Keuangan, (2) Akuntansi Sektor Publik, (3) Akuntansi Manajemen.

\section{Tabel 11}

\begin{tabular}{|l|r|r|r|r|r|}
\hline \multicolumn{7}{|c|}{ Faktor-faktor tidak tertarik Pekerjaan SIA } \\
\hline \multirow{2}{*}{ Valid } & Materi SIA Sulit & Frequency & Percent & $\begin{array}{c}\text { Valid } \\
\text { Percent }\end{array}$ & $\begin{array}{c}\text { Cumulative } \\
\text { Percent }\end{array}$ \\
\cline { 2 - 6 } & Tidak Merasa cocok & 2 & 8.7 & 8.7 & 8.7 \\
& Total & 21 & 91.3 & 91.3 & 100.0 \\
& & 23 & 100.0 & 100.0 & \\
\hline
\end{tabular}

Sumber: Data primer yang telah diolah, 2020 


\section{PENUTUP}

Penelitian ini bertujuan mengeksplor faktor-faktor yang menentukan mahasiswa memilih karir di bidang Sistem Informasi Akuntansi. Berdasarkan hasil statistik deskriptif dapat disimpulkan bahwa: Mahasiswa yang tertarik dibidang SIA lebih tinggi dibandingkan yang tidak berminat, Mahasiswa yang tertarik dibidang SIA yang paling penting dipertimbangkan adalah (a) Mudah memahami SIA, (b) Saran Dosen Pembimbing Skripsi, (c) Saran Dosen, (d) Gaji tinggi, (e) Minat di bidang SIA, yang nilai rata-rata diatas 4, Mahasiswa yang tidak tertarik dibidang SIA dari delapan faktor, hanya ada 2 yang menjadi penyebab, yakni merasa tidak cocok dibidang SIA dan Bidang SIA sangat sulit

Berdasarkan kesimpulan yang ada menunjukkan bahwa mahasiswa masih memiliki keinginan dan ketertarikan di bidang SIA akan tetapi adanya keterbatasan ke ilmuan baik secara konsep maupun praktis karena tidak ada konsentrasi SIA, yang hanya tersedia tiga konsentrasi utama, yakni: Akuntansi Keuangan, Akuntansi Sektor Publik dan Akuntansi Manajemen. Untuk mendukung hasil penelitian, maka sebaiknya pihak-pihak pengambilan keputusan di Kampus untuk mengambil kebijakan untuk segera mebuka konsentrasi baru dan menyediakan infrastruktur baik software maupun hardware dan memberikan kesempatan kepada Dosen SIA untuk meningkatkan keilmuan baik melalui studi lanjut maupun workshop-workshop yang berhubungan dengan SIA.

Hal ini penting karena mahasiswa yang tidak tertarik dibidang SIA salah satu penyebabnya merasa mata kuliah SIA sulit dan tidak memiliki kecocokan dibidang SIA yang kesemuannya merujuk pada ketidakmampuan dibidang SIA yang artinya tidak ada pendukung baik secara Akademik berupa minat konsentrasi di bidang SIA, pengembangan sumberdaya dan infrastruktur.

\section{DAFTAR PUSTAKA}

Abbott, T. 2001. Social and personality development, Routledge Taylor \& Francis Group, New York.

Adler, P. 2002. Corporate scandals: It's time for reflections in business schools. Academy of Management Executive, 3(16), 1-12.

Alchieri, J. C. dan Charczuk, S.B. 2003. The Choice of Career: Aspects of Decision-making Among University Entrance Examinees. Aletheia, Vol. 15, pp. 7 - 14.

Afolabi, M. 1996. Holland's typological theory and its implications for librarianship and libraries, Librarian Career Development, vol. 4, no. 3, pp. 15-21.

Arens, A. A., \& Elder, R. J. 2006. Perspectives on auditing education after Sarbanes-Oxley. Issues in Accounting Education, 4, 345-362.

Arnold, V. \& Sutton, S. G. 2007. The impact of enterprise systems on business and audit practice and implications for university accounting education. International Journal of Enterprise Information Systems, 4(3), 1-21.

Bandura, A. 1977. Self-efficacy: toward a unifying theory of behavioral change, Psychological Review, vol. 84, no. 2, pp. 191-215. 
Bandura, A. 1982. Self-efficacy mechanism in human agency, American Psychologist, vol. 37, pp. 122-147.

Bandura, A. 1997. Self-efficacy: the exercise of control, W.H. Freeman and Company, New York.

Bandura, A., Barbaranelli, C., Caprara, GV., Pastorelli, C. 2001, Self-efficacy beliefs as shapers of children's aspirations and career trajectories, Child Development, vol. 72, no. 1, pp.187206.

Baruch, Y. 2004, Transforming careers: from linear to multidirectional career paths organisational and individual perspectives, Career Development International, vol. 9, no.1, pp. 58-73.

Betz, NE. 2004, Contributions of self-efficacy theory to career counseling: a personal perspective, Career Development Quarterly, June, viewed 25 August 2019, <http://www.entrepreneur.com/tradejournals/article/120354606.html>.

Beyer, S. 2008. Gender differences and intragender differences among management information systems students. Journal of Information Systems Education, 19(3), p. 301-310.

Bungin, B. 2010. Penelitian Kualitatif. Komunikasi, Ekonomi, Kebijakan Publik dan Ilmu Sosial Lainnya. Kencana Prenada Media Groups.

Brown, D. 2002. Introduction to theories of career development and choice: origins, evolutions, and current efforts, in D Brown and Associates (eds), Career choice and development, 4th edn, Jossey-Bass: A Wiley Company, San Francisco.

Curtis, M. B., Jenkins, J. G., Bedard, J. C., \& Deis, D. R. 2009. Auditors' training and proficiency in information systems: A research synthesis. Journal of Information System, 1(23), 79-96.

Croasdell, D., A. McLeod and M. G. Simkin. 2011. Why Don't More Women Major in Information Systems. Information Technology \& People, Vol. 24 No. 2, pp. 158 - 183.

Crampton, W., Walstrom, K, \& Schamback, T. 2006. Factors influencing major selection by college of business majors. Issues in Information Systems, VII(1), p. 226-230.

Downey, J., McGaughey, R., \& Roach, D. 2009. MIS versus computer science: an empirical comparison of the influences on the students' choice of major. Journal of Information Systems Education, 20(3), p. 357-368.

Downey, J., McGaughey, R., \& Roach, D. 2011. Attitudes and influences toward choosing a business major: The case of information systems. Journal of Information Technology Education, 10, p. 231-251.

Esters, LT \& Bowen, BE. 2004, Factors influencing enrolment in an urban agricultural education program, Journal of Career and Technical Education, vol. 21, no. 1, pp. 25-37. 
Fransesco, W.H., Noland, T.G., and J.A. Kelly. 2003. Why Don't Students Major in Accounting?. Southern Business Review, Vol. 29, No. 1, pp.37-40

Gilbert, GR, Sohi, RS \& McEachern, AG. 2008, Measuring work preferences: a multidimensional tool to enhance career self-management, Career Development International, vol. 13, no. 1, pp. 56-78.

Gushue, G. 2006, The relationship of ethnic identity, career decision-making self-efficacy and outcome expectations among Latino/ a high school students, Journal of Vocational Behavior, vol. 68, pp. 85-95.

Gushue, GV, Scanlan, KRL, Pantzer, KM \& Clarke, CP. 2006, The relationship of career decision-making self-Efficacy: vocational identity and career exploration behavior in African American High, Journal of Career Development, vol. 33, no. 1, pp. 19-28.

Holland, J. 1992, Making vocational choice: a theory of vocational personalities and work environments, 2nd edn, Psychological Assessment Resources, Inc., Florida.

Hogan, R \& Blake, R. 1999. John Holland's vocational typology and personality theory, Journal of Vocational Behavior, vol. 55, pp. 41-56

Ituma, A \& Simpson, R. 2007. Moving beyond Schein's typology: individual career anchors in context of Nigeria, Personnel Review, vol. 36, no. 6, pp. 978-995.

Johnson, MK \& Mortimer, JT. 2002. Career choice and development from a social serspective, in D Brown and Associates, Career choice and development, 4th edn, JosseyBass A Wiley Company, San Francisco.

Leong, L \& Tracey TJG. 2006. Structure of RIASEC scores in China: a structural metaanalysis, Journal of Vocational Behavior, vol. 68, pp. 39-51.

Toit, R \& Bruin, GP. 2002. The structural validity of Holland's R-I-A-S-E-C model of vocational personality types for young black South African men and women, Journal of Career Assessment, vol. 10, no. 1, pp. 62-77.

Marshall, V \& Bonner, D. 2003. Career anchors and the effects of downsizing, implications for generations and cultures at work: a preliminary investigation, Journal of European Industrial Training, vol. 27, no. 6, pp. 281-291.

McInerney, C.R, N. C. Didonato, R. Giagnacova, A. M. O’Donnell. 2008. Students' Choice of Information Technology Majors and Careers: A Qualitative Study. Information Technology, Learning, and Performance Journal, Vol. 24 No. 2, pp. 35 - 53

Mitchell, LK \& Krumboltz, JD. 1996. Krumboltz's learning theory of career choice and counseling', in D Brown, L Brooks \& Associates (eds), Career choice and development, 3rd edn, Jossey-Bass, San Francisco.

Nazir, M.1998. Metoda Penelitian. Ghalia Indonesia: Jakarta 
Kuechler, W., McLeod, A., \& Simkin, M. 2009. Filling the pipeline for IS professionals: What can IS faculty do? Journal of Information Systems Education, 18(1), p. 407-415.

Kumar, A. \& Kumar, P. 2013. An examination of factors influencing students selection of business majors using TRA framework. Decision Sciences, 11(1), p. 77-105.

Krumboltz, JD. 1979. A social learning theory of career decision-making, in AM Mitchell, GB Jones \& JD Krumboltz (eds), Social Learning and career decision-making, Carroll Press, Cranston, RI.

Salami, SO. 2008, Role of personality, vocational interests, academic achievement, and sociocultural factors in educational aspirations of secondary school adolescents in southwestern Nigeria, Career Development International, vol. 13, no. 7, pp. 630-647.

Schein, EG. 1978, Career dynamics: matching individual and organizational needs, AddisonWesley Publishing Company, Massachusetts.

Schein, EG. 1990, Career anchors: discovering your real values, Pfeiffer \& Company, San Diego.

Sekaran, U dan Bougie, R. 2009. Research Methods for Business. A Skill Building Approach. John Wiley \& Sons Ltd.

Sharf, R. 2002. Applying career development theory to counseling, 3rd edn, Brooks/Cole Thomson Learning, Australia.

Sharf, R. 2006, Applying career development theory to counseling, 4th edn, Thomson Brooks/ Cole, Australian.

Sugiyono. 2005. Metoda Penelitian Bisnis. Bandung: Alfabeta

Suutari, V \& Taka, M. 2004, Career anchors of managers with global careers, Journal of Management Development, vol. 23, no. 9, pp. 833-847.

Stewart, J \& Knowles, V. 2000, Graduate recruitment and selection: implications for HE, graduates and small business recruiters, Career Development International, vol. 5, no. 2, pp. 65-80.

Spokane, AR, Luchetta, EJ \& Richwine, MH. 2002, Holland's theory of personalities in workenvironments, in D Brown and Associates (eds), Career choice and development, 4th edn, Jossey-Bass: A Wiley Company, San Francisco.

Swanson, JL \& Fouad, NA 1999, Career theory and practice: learning through case studies, SAGE Publications, Inc. California.

Pan, G., Seow, P.-S., Chan, C., \& Lim, C.-Y. 2015. Analytics and cybersecurity: The shape of things to come. Singapore: CPA. 
Patton, W \& McMahon, M. 1999. Career Development and systems theory: a new relationship, Brooks/Cole Publishing Company, Pacific Grove.

Prideaux, L. 2001, The career choice cycle course, in W Patton \& M McMahon (eds) Career development programs: preparation for lifelong career decision-making, Acer Press, Melbourne.

Pollacia, L. \& Lomerson, W. 2006. Analysis of factors affecting declining CIS enrollment. Issues in Information Systems, VII(1), p. 220-225

Roger, ME, Creed, PA \& Glendon, AI. 2008, The role of personality in adolescent career planning and exploration: a social cognitive perspective, Journal of Vocational Behavior, doi:10.1016/j.jvb.208.02.002, viewed $20 \quad$ September 2010, <http://www.sciencedirect.com>.

Upping, P. and J. Oliver. 2012. Thai Public Universities: Modernisation of Accounting Practices. Journal of Accounting \& Organizational Change, Vol. 8 No. 3, pp. $403-430$

Vandenbosch, B., \& Ginzberg, M. J. 1997. Lotus notes and collaboration: Plus ca change. Journal of Management Information Systems, 3(13), 65-82.

Vatanasakdakul, S. and C. Aoun. 2011. Why Don't Accounting Students Like AIS?. International Journal of Educational Management, Vol. 25 No. 4, pp. 328 - 342.

Walstrom, K. A., T. P. Schambach, K. T. Jones, and W. J. Crampton. 2008. Why Are Students Not Majoring in Information Systems. Journal of Information Systems Education, Vol. 19 No. 1, pp. $43-54$.

Zhang, W. 2007. Why IS: Understanding Undergraduate Students' Intentions to Choose and Information Systems Major. Journal of Information Systems Education, Vol. 18 No. 4: pp. $447-458$. 